\title{
The Letter of Jude and Graeco-Roman Invective
}

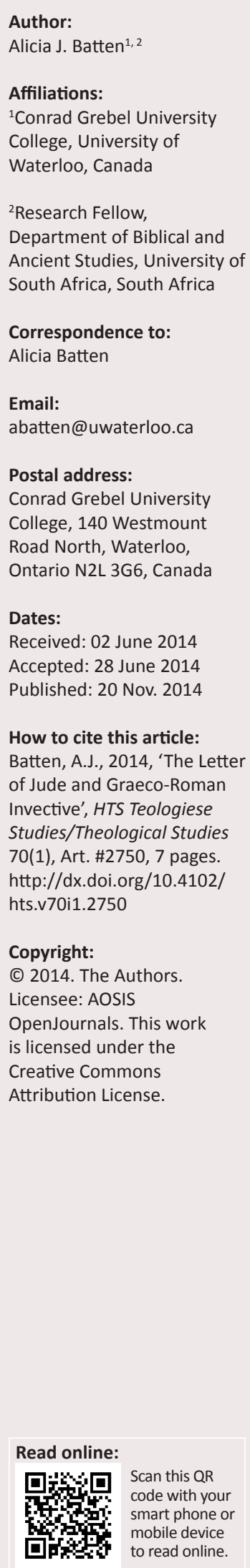

Many have attempted to identify the opponents in Jude and have addressed the manner in which the author characterises this group. Moreover, scholars have expended considerable energy on the analysis and explication of Jude's rhetorical structure and style, and there is wide consensus that as a text, Jude is a sophisticated letter. However, less work has attended to the evaluation of Jude within the tradition of Graeco-Roman invective. In comparing verses from Jude to some examples from such literature, we find similar themes. In particular, the letter of Jude and some Graeco-Roman moralists engage in a particular tactic to undermine, even destroy, the character of their opponents. They both present them as effeminates, which, although a stereotype, is one of the worst insults a writer or orator could wage against an adversary. This article argues that Jude engages in such character assassination, invoking effeminacy in the manner that he describes his opponents' behaviour, and placing them in a long line of debauched and condemned figures from ages past.

\section{Introduction}

Historically, the letter of Jude has not been a favourite among biblical scholars. ${ }^{1}$ Although it has received compliments as a well-structured, rhetorically adept, and linguistically sophisticated document (Neyrey 1993), overall, its disputed authorship, unknown provenance, brevity and polemical tone have not assisted the letter in attracting much attention or appreciation from many interpreters within the Christian tradition. ${ }^{2}$ Comparable to the other 'general' or 'catholic' epistles, however, there has been a rise of interest in Jude in recent years. Using a variety of newer methods, interpreters not only examine Jude's style and rhetoric, but how it functions sociologically. ${ }^{3}$

This brief discussion does not attempt to approach Jude from a novel methodological viewpoint, but it does adopt as its focus the characterisation of the opponents targeted by the letter. Many would agree that the aim of Jude is to cast aspersions upon a group of people; it is 'preoccupied with a vehement polemic against false teachers' (Wisse 1972:134), and considerable efforts have been made to understand the nature of this criticism. The identity of these heretics has also been much debated. For some time Gnostics or a precursor group to Gnosticism were named as the most likely people targeted by both Jude and 2 Peter, the latter using most of Jude as a source (e.g. Kelly 1969:231). However, a relatively recent re-examination has pointed out that such a determination is not conclusive, for the evidence that persuaded some interpreters that these people were Gnostics, or an early incarnation of Gnosticism, such as the reference to 'dreamers ... [who] defile the flesh' in Jude 8, is not unique to the so-called Gnostic teachers, even in the 2nd century (Desjardins 1987:94). As it currently stands, interpreters are not sure who these opponents are; indeed, no consensus about their identity has been reached. Frederik Wisse even argued that the description of the false teachers indicates that they may not be a specific or historical group at all, and their characterisation conforms to a very traditional depiction of eschatological false prophets. For Wisse, Jude is not attempting to combat heresy nor is he seeking to expel false teachers. Rather, the author employs traditional eschatological imagery from Judean and early Christian literature to set up a group of false prophets in order to emphasise that the enemies of the last days have arrived, that Christians must be ready and prepared, and that the Parousia is near (Wisse 1972:142).

Although Wisse's thesis has not been widely accepted, he has contributed significantly to understanding the traditional nature of the characterisation and its various sources within 1.For example, Rowston (1975) titles his article on Jude in New Testament Studies, 'The most neglected Book in the New Testament'.

2.The authorship of Jude was disputed within the early church, which made it less appealing, and Luther, although he valued the book, did not consider it a foundational text for the Christian faith (Pelikan 1963). For a brief review of the canonical debates about Jude, see Kelly (1969).

3.The 2008 a collection of essays of Jude, edited by R.L. Webb and P.H. Davids, engages questions of purity and pollution in the letter, how postcolonial theory can illuminate the text, as well as other examinations of its persuasive power. 
heresiological writings. What I seek to do, in addition, is to point to other dimensions of what I will call 'vilification literature' from antiquity, namely Graeco-Roman invective that was used for the purposes of promoting particular types of morality. Used most effectively by satirists and others, invective could define what it meant to be an elite person, exclude others, and control the behaviour of a particular group (Edwards 1993:12). Thematically, one can trace parallels between Graeco-Roman literature and Jude even though Jude also draws upon uniquely Judean traditions. I will argue that Jude shares this use of invective precisely because it is seeking to undermine its opponents, just as the Graeco-Roman writers were attempting to do. Comparable to these authors, Jude focuses in on a particular and stereotypical kind of accusation or condemnation: the false teachers are effeminates, which was a signifier, one could say, for all sorts of immorality and decadence. ${ }^{4}$ Jude demonstrates the vile character of these degenerates, and connects them to a long line of debauched characters from ages past.

\section{General literary, rhetorical and theological features of Jude}

Although there are many textual corruptions in this short missive (Allen 1998:133), there has long been appreciation for many of the literary features in Jude. Fifteen hapax legomena emerge in this short letter, and three other words are found only in 2 Peter and are clearly dependent upon Jude as the source text. In addition, Jude employs 22 words found only rarely throughout the New Testament. Jude is especially interesting too, because it uses such a variety of Judean traditions such as the references to Cain, Balaam and Korah (v. 11), Enoch (Jude 14), an allusion, it seems, to the Testament of Moses (Jude 9) and an actual citation from 1 Enoch (Jude 14-15) among others. These factors are all indications that the author is educated in an 'environment which contained considerably more than Hebrew and Christian Scriptures' (Neyrey 1993:29).

Jude is a unified text, manifests the conventions of a genuine letter and reflects many common dimensions of ancient rhetoric. Watson (1988:77-78) has traced a clear rhetorical structure throughout the letter whereby following an epistolary prescript (Jude 1-2), Jude contains an exordium (Jude 3), which outlines the author's intention and endears the audience to him; narratio (Jude 4) or statement of facts or charges against the opponents; two probatio (Jude 5-10;11-13) or 'proofs' of why the opponents are ungodly and subject to judgement. Within these proofs, Jude draws upon examples from the past, comparisons and prophecies. Jude 17-23 forms the peroratio or conclusion which repeats the charges laid against the false teachers, followed by a doxology in Jude 24-25. For Watson, Jude is primarily deliberative rhetoric in that it seeks to discourage the audience from associating with the false teachers, who have invaded the group. Within this overall deliberative frame (Charles 1993:62), however, there appears a heavy dose of epideictic, as Jude engages strong

4.On the effeminate as a stereotype, see Richlin (1992:87-93). language and rich imagery to provoke negative feelings towards these opponents; 'all with the intent of dissuading the audience from falling prey to their teaching and practice' (Watson 1988:79). ${ }^{5}$

Within this overall structure, Jude engages in a synkrisis or 'comparison' of the behaviours of the 'beloved' whom he addresses, and the other group, often termed 'those people,' whose comportment is vilified (Neyrey 1993:24). ${ }^{6}$ These contrasts have a 'conspicuously moral quality' (Charles 2008:88) insofar as it is types of conduct that are opposed to one another. The author also utilises triplets, such as 'mercy, peace, and love' in Jude 2 (Mayor 1907:lvi). These triplets create a rhythm throughout, constituting 'amplification by accumulation' (Watson 1988:42). The attacks on the false teachers appear in groups of three, as in Jude 4, when they are described as ungodly, perverting the grace of God and denying Jesus Christ; as well as in Jude 8, when they defile the flesh, reject authority and revile the glorious ones. Overall, the letter is elegantly structured, with an inclusio that connects the opening of the letter to the closing with the repetition of terms such as 'kept' and 'keep' (Jude 1 \& 21), as well as a recurrence of certain words within various sections of the letter such as 'godless' (Jude 4, 15, 18).

The language of purity and pollution also figures importantly in shaping Jude's theological worldview. Persons are classified as to whether they are pure (the 'beloved') or polluted ('those ones' - the opponents). This contrast of purity and pollution pervades the document, with references to the 'saints' ( $\dot{\alpha} \gamma$ íors) in Jude 3, to building up in the 'most holy' ( $\dot{\alpha} \gamma 1 \omega \tau \alpha \dot{\alpha} \tau)$ faith and praying in the 'holy' ( $\dot{\alpha} \gamma i \omega)$ spirit in Jude 20, and the audience being presented

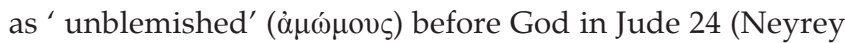
1993:39). In contrast, the false teachers 'pervert' the grace of

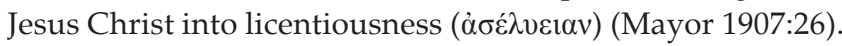
They are associated with the sexual immorality of Sodom and Gomorrah (Jude 7) and called $\sigma \pi \imath \lambda \alpha \dot{\delta} \delta \varsigma$ or 'blemishes' in Jude 12. The latter is a debated translation, for $\sigma \pi \imath \lambda \alpha \dot{\delta} \delta \varepsilon \varsigma$ more often refers to hidden rocks or reefs (Bauckham 1983:85), but given that 2 Peter took the word to mean 'blemish' (in addition to some other early commentators), the fact that it forms a direct contrast to the 'unblemished' audience, as well as its link to the 'stained' or 'blemished' ('̇ं $\pi \imath \lambda \omega \mu \varepsilon$ vov) garment in Jude 23 (see Richard 2000:278-279), 'blemishes' seems a reasonable interpretation.

In addition, each person has his or her proper place. The 'beloved' are in the correct place, 'kept for Jesus Christ' (Jude 1) and where they must 'keep' themselves in the love of God (Jude 21) whereas the opponents are out of place. They have crept in to where they do not belong (Jude 4) and as

5. For a more recent review of the rhetorical and epistolary structure of Jude, the possibility of Midrashic features, in addition to discussion of chiastic pattern possibility of Midrashictures, and other stylistic features, see Charles (2008). Charles thinks that all of these approaches to the structure and argument of Jude are relevant, with different
methods yielding different and illuminating insights about the letter.

6.Joubert (1995:80) identifies Jude's overall strategy as 'positive/negative presentation' strategy. The implied readers are presented positively while the opponents are characterised in a very negative manner. 
Neyrey points out, they appear to have no place, as they are waterless clouds, drifting in the wind, and uprooted, fruitless trees (Jude 12). They are wild waves, wandering stars (Jude 13) and compared to angels in Genesis 6 who left their proper place and are now kept in eternal chains until judgement day (Jude 6) (Neyrey 1993:38).

The letter writer is frustrated by the fact that some of the impure have apparently infiltrated the group, thereby effectively infecting the community of the godly that he addresses. Jude writes to counter this perceived invasion, and does his best to convince the audience that the opponents are ungodly and destined for eternal condemnation; in fact, these are the ones of whom it was prophesied would suffer punishment (Jude 14-15, 17-18). He does not wish his audience to associate with these false teachers, for such association would pollute them and alienate them from God and the possibility of eternal life.

Jude is a deeply 'Judean' (no pun intended) document, yet as widely agreed, many 1st and 2nd century Judeans were sophisticated Greek speakers, living in communities within cities and towns throughout the Roman Empire. There is no reason why the author of this text would not come into contact with literary traditions and share some of the cultural values of the Roman Empire, especially given his facility and skill with the Greek language and literary patterns. In the next section, therefore, I will discuss a few features of Roman moralising discourse, particularly its use of invective, which are illuminating for the analysis of Jude.

\section{Effeminacy in Graeco-Roman invective}

One of the reasons why it is commonplace to imagine ancient Rome as a decadent and depraved society is that so much literature survives decrying its decline. Indeed, the lament over the deterioration, particularly of Roman values, is prevalent in much literature of the 1st century. Criticisms of luxury, of 'softness' and overindulgence were part of an overall anxiety about the identity and power of the Roman Empire. Cicero, Pliny and many others, such as the elder Cato, Martial, Horace, Juvenal and Varro, bemoan the softness of Roman males, for being soft meant that one was womanly, porous and passive. This threatened the Roman ideal of masculinity which stressed strength, virility, and above all, self-control. ${ }^{7}$ The weakening of this ideal was perceived to have political consequences because effeminate men were not perceived to be strong or reliable leaders. They were risks, in fact. ${ }^{8}$ This model of masculinity was also true for the Greek imagination. Greek writers such as Dio Chrysostom call non-Greeks 'girly' (To the People of Alexandria 32.3). For many Greek authors, a true man was a public figure, and was

7.As Corbeill (1997:107) makes clear: An effeminate man threatened the Roman male.'

8.In one of his letters to his friends (16.27.1), Cicero indicates considerable concern about two consuls, Hirtius and Pansa, who are lusting and lounging around in
effeminate ways. He is worried that given their womanly behaviour, there will be political disasters. required to 'have leadership over oneself' (Moxnes 1997:270271), especially restraint and self-control in all dimensions of life, including finances, eating, sexual activity, speaking, emotions, and of course, politics.

Moralists target many people, including Eastern kings whose empires are the sources of the majority of luxury items being imported to Rome, causing greed for more and contributing to the decay of this masculine ideal. In his sole surviving work, the History of Alexander the Great, Quintus Curtius depicts the kings of India as effeminates, claiming that they bathe in perfume, attend far too much to their hair, and even hold formal meetings while their hairdressers work on them (8.22). In Rome, greed was particularly associated with women (but men certainly were not exempt), who are often attacked for lavish displays of jewels, fabrics, and complicated hairstyles. In one of his epigrams, Martial, for example, sneers at a woman named Gellia, who, he claims, swears oaths not by the gods, but by her jewels, which she adores far more than her two sons (Epigram 8.81). In fact, 'foreignness and femininity' were often at the heart of Roman moralising invective (Upson-Saia 2011:15-18), for outsiders and women were both perceived as significant causes for the deterioration of a noble past.

Invective was pervasive throughout the world of Mediterranean antiquity. Whether it is in a graffiti scrawled upon a wall, epithets, gossip, or the more sophisticated genres of satire and oration, invective surfaces in many places throughout Graeco-Roman forms of communication:

Giving your opponent a female name, the use of epithets or strings of epithets, insinuations, combinations of seemingly contradictory vices - all can be found in graffiti and gossip, as well as in the orations. (Richlin 1992:101)

It was expected that rivals would hurl insults against one another, and political leaders were proud, to some extent, of their ability to withstand brutal criticism and abuse (Richlin 1992:103). Thus invective was not particularly surprising or shocking; rather, it was an anticipated form of expression that the public noticed. Although these sorts of attacks upon people were not always taken literally, as themes and tropes were repeated over and over, they were by no means meaningless and were heard or read seriously by the public (Edwards 1993:11). In agonistic cultures, in which people are constantly jostling for honour, power and resources, such insinuations, arguments and brawls are commonplace.

Writers would regularly undermine their political opponents by questioning their masculinity (Richlin 1992:97), and this could be done through various means. A good deal of energy was spent on detecting effeminacy based upon the walk, gestures, voice, dress, adornment and banqueting, which involved eating, drinking, dancing and sex (Corbeill 1997; Gleason 1990). The indulgences of banqueting, sexual excess and overspending were linked together as related vices that often came under attack. Catullus, for example, thinks that gluttony is linked to 
unquenchable desires for more money and more sex (Richlin 1988:361). ${ }^{9}$ Cicero refers to his adversary Gabinius as overtaken by drink, eating, pimping and adultery (Pro Sestio 20; see Corbeill 1997:104). One defect or evil was linked to many; and the 'rhetorical handbooks instruct that if an opponent can be shown to be guilty of one vice, it is then possible to implicate him in many others' (Corbeill 1997:104). ${ }^{10}$ Key here is the fact that the enemy must be shown to be guilty, which means that concrete examples of debauchery must be provided. Effective invective, if you will, relied upon proof. As Corbeill (1997:112) makes clear, invective 'requires external, visible means of verification' and there was a consistent group of characteristics that 'were thought to characterise a dissipating masculinity'.

One of the most obvious means of undermining the masculinity of the adversary was through providing examples of aberrant sexual misconduct. Although specific activities are named or suggested, it is not the activities themselves which are the focus, but what they mean about the character of the participants. Often, writers made an appeal to 'nature', which was itself a 'powerful rhetorical weapon' (Edwards 1993:88), and which presupposed that there were specific sexual roles for women (to be penetrated) and adult men (to penetrate). Slaves and boys could also be penetrated, but once the boys became men, such a position would be deemed 'unnatural'. For the Romans and Greeks, the standard protocols stressed a strict dichotomy whereby the sexually active were adult males, and everybody else, even non-citizens, was naturally 'passive' (Walters 1997:31). Thus whether one was engaging in sex with a male or female, slave or citizen, was an important ingredient in invective. Likewise, the degree to which one participated in sexual activities was a factor. At first such accusations may seem contradictory, for the same people accused of passive behaviour are also perceived as never satisfied. Edwards (1993) explains:

In the eyes of Roman moralists, the effeminate were like women in playing a 'passive' sexual role but at the same time they were like women in having an excessive interest in sex. The appetites of the effeminate were uncontrollable. They were adulterers as well as catamites. (p. 81)

Thus passive sex or excessive sex was fodder for invective. Both were understood to be 'unnatural' just as women who, according to Seneca, behaved like men by partying late into the night, wrestling with men and vomiting up their wine. Such actions were violations of the natural order (Epistles 95.20-21). Authors would thus make it clear that so-and-so was engaging in unnatural sexual activity; a sign that the individual had little control.

Another association often made with effeminates had to do with their eating habits. Eating luxurious and expensive foods was perceived by many authors as indulgent. In his

9.Richlin (1988:355) observes that references to food belong to the erotic in Latin lith (whe of food on the table belongs to the erotic, whereas the mechanics of ingestion and excretion belong to invective.'

10.See, for example, the Rhetorica ad Herennium 2.5.
Offices, Cicero even includes fishmongers, butchers, cooks, poulterers and fishermen as shameful professions as they cater to the decadent lifestyles of others (1.150; see Edwards 1997:83). Interestingly, being fat or portly does not receive much attention (Corbeill 1996:142-143), but the consumption of rich foods was expensive, and thus associated with uncontrollable spending habits. In both Greek and Latin, verbs of eating and devouring were regularly associated with bankruptcy and monetary splurging (Corbeill 1996:132).

Consuming rich food usually took place in the context of the banquet, the site of all sorts of goings on. Often a victim of Cicero's pen, the former consul Gabinius is targeted for his predilections for banqueting and having sex (For Sestio 26) and is clearly described by Cicero as an effeminate (For Sestio 18). It is in the context of feasting where all sorts of unsavoury activities took place, and thus anything associated with banqueting, including eating, dancing and having sex, became the source of sometimes vicious attacks. As Corbeill (1997:103) indicates, 'charges characteristic of political invective - gluttony, financial mismanagement, political ineptitude, and sexual profligacy (especially between men) - intersect in the dark and mysterious arena of the banquet'. The association of an individual with a lavish dinner party would thus suggest all kinds of inappropriate behaviours.

One more stereotype associated with effeminates in antiquity was how they spoke and what they said. A weak, shrill or high voice was suspicious (Dio Chrysostom Orations 33.52). 'Female' characteristics included deceitful speech (PseudoAristotle, Physiognomy 810a 1-8). Greek literature often identified the chameleon-like person, who cajoles and flatters, with the effeminate male (see Theophrastus Characters 2; Kamen 2014:408). Such flattery and fawning, as well as emotional outbursts, were associated with women, who were perceived generally as lacking in self-control. Tacitus, for example, refers to a certain Otho as writing letters full of womanish flattery (Histories 1.74), while Edwards (1993:93) indicates that as 'womanly' men lacked physical strength, they were accused of resorting to lies and flattery to achieve their ends. ${ }^{11}$

All of the characteristics discussed are connected to an overall vice identified within Graeco-Roman literature: a lack of self-control. A mastery over appetites was necessary when it came to food, drink, sex and emotional displays. Too much attention to dress and preening, or a particular way of gesturing, scratching one's head, or walking, attracted scrutiny. Spending too much time with one's wife could prompt suspicions of effeminacy for it meant that one lacked the self-control necessary to remain apart from her when necessary. It suggested that one may be having too much sex, which was commonly thought to weaken men. Moreover, this pursuit of private pleasures was condemned because it indicated that the adult male was putting his own desires ahead of those of the state. Plutarch reports that even

11.The image of the flatterer was notorious within Graeco-Roman literature. In his essay, How to tell a flatterer from a friend, Plutarch called them 'apes' (52B) who simply prance about, soothing and cajoling in order to serve their own interests. 
Pompey was accused of this (Pompey 48.5-7; see Edwards 1993:85). The true man; the true public servant, must possess self-control. As Williams (1999:141) sums it up: 'Masculinity was not fundamentally a matter of sexual practice; it was a matter of control.'

There was a range, therefore, of behaviours that could elicit a charge of effeminacy. Such attacks were a primary means of undermining the adversary, even if the audience knew that aspects or details of the accusations and claims may have been questionable. They reflect widespread worries about Greek and Roman identities, power and status, which were bound up within ideologies of masculinity. It is not surprising that early Christian authors, embedded as they were within the Roman Empire, should reflect similar anxieties.

\section{Invective in Jude}

Given how many verses Jude devotes to undermining his opponents, it is fair to say that a significant aim of the letter is to engage in character assassination. Jude is concerned that these false teachers may influence the people to whom he writes. Drawing from his particular set of resources, therefore, he wages an attack on them that, in addition, shares themes and characteristics of Graeco-Roman invective.

In Jude 4, the author presents his main propositions, or narratio, as mentioned above. The narratio identifies the exigence of the letter and the 'points upon which the rhetor would like the audience to render judgment' (Watson 1988:43). Here Jude refers to people who were long ago condemned, but who have secretly gained admission to the community. They have turned away from God's favour to licentiousness ( $\dot{\alpha} \sigma \varepsilon \dot{\lambda} \gamma \varepsilon \varepsilon \alpha v)$ and deny Jesus Christ. Thus in the opening proposition of the letter, which first introduces the opponents, we have an explicit reference to debauchery or licentious behaviour. According to Mayor (1907:26), who builds from Lightfoot's work on Galatians 5:19, the word

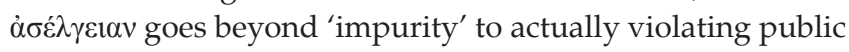
decency. The opponents are depicted as sensualists of some sort; they have traded in God's favour for debauchery.

Jude 5 then provides some historical examples of characters comparable to the opponents, as proof that such figures received judgement. Firstly, the text contrasts the faithful who were rescued from Egypt with those who did not uphold their faith and were destroyed. Directly following in Jude 6 is a description of the angels who left their proper dwelling place; these beings were subsequently enchained until judgement day. This reference is commonly thought to allude to the tale of the 'sons of God' from Genesis 6:1-4 who procreated with the daughters of humans; a story retold and elaborated in 1 Enoch. In the latter text, such figures are referred to as angels, watchers, or children of heaven, who abandoned high heaven and defiled themselves with women (1 Enoch 12). Likewise, in verse 7 the people of Sodom and Gomorrah (Gn 19:4-11) and surrounding cities are called out

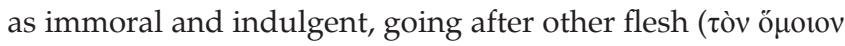

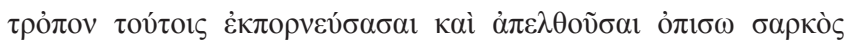

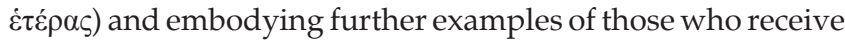
eternal punishment. Two of the three examples explicitly refer to sexual immorality, thus continuing the association of the false teachers with the licentiousness identified in verse 4. Clearly, this sexual lust violates Jude's sense of a natural or 'God given' order (Bauckham 1983:54) to things and is a dimension of the invective that he wants to stress. Again, the verse functions as historical evidence that such sinful behaviour receives divine punishment (Watson 1988:53).

In verse 8 , Jude again explicitly attacks the opponents,

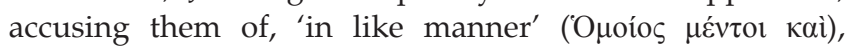

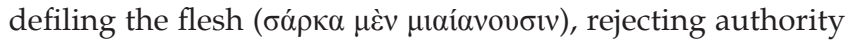
and slandering the 'glorious ones'. This verse maintains the connection to sexual sinfulness, while verses 9 and 10 amplify it. They indicate how shocking the opponents' behaviour is, for even the archangel Michael did not revile a higher authority when he fought with the devil, yet these false teachers revile whatever they do not understand and are destroyed by the things that they know instinctively, like irrational animals. The latter part of verse 10 recalls the licentiousness of verse 8 with its reference to $\varphi v \sigma i \kappa \tilde{c} \varsigma$ which corresponds to 'flesh' (бó $\kappa \kappa \alpha)$. The opponents understand 'flesh' at an instinctual level. As Bauckham puts it, though the adversaries 'claim to be guided by the special spiritual insight gained in heavenly revelations, they are in fact following the sexual instincts which they share with the animals' (1983:63). Humans were compared to animals positively and negatively in antiquity, with animal epithets occasionally popping up in invective (Richlin 1992:100). Sometimes the comparison to irrational animals was intended to highlight a lack of self-control and excessive appetite for food and sex (see Clement of Alexandria The Pedagogue 2.1.14). The lack of control for the latter is probably what this verse intends to convey. ${ }^{12}$

Verse 11 begins a second proof that these false teachers are 'ungodly' and subject to judgement by furnishing a prophecy of woe against these evildoers who walk the way of Cain, abandon themselves for gain, like Balaam, and die in Korah's rebellion. Cain is not a surprising example, for he becomes one of the most infamous villains in post-biblical traditions. The reference to Balaam is opposite to the story in Numbers 22:18, where Balaam refuses to curse Israel for financial gain, but in subsequent Judean traditions he does do this, and persuades Balak to lead Israel into sexual sin and idol worship. As Watson says, by using the Balaam example, 'Jude claims that the sectarians lead the audience into sexual immorality and receive monetary reward for their teachings' (Watson 1988:59).

This prophecy is then applied to the opponents in verse 12. Here, we find an intriguing reference to feasting

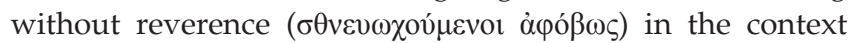
of fellowship meals. Probably what Jude is strongly insinuating is that these sensualists treat the agape meals as mere banquets, recklessly engaging in the licentiousness and gluttony that such contexts often bred (Bauckham 1983:86).

12.On the comparison of humans to animals in 2 Peter (which builds from Jude), see Callan (2009). 
What is also underscored is the fact that the false teachers focus on their own interests (v. 12). They are portrayed as unconcerned with the well-being of the larger community, but are like shepherds who only look after themselves

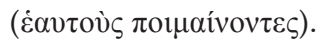

Verses 12 and 13 then incorporate a series of metaphors drawn from nature such as waterless clouds, which are carried by the winds, and uprooted trees that do not bear fruit. These metaphors strongly suggest that the enemies are completely out of control. Even more vivid is the description of them as wild waves of the sea, casting up the foam of their own 'shame' ( $\alpha i \sigma \chi v$ vos). The latter may well refer to a Greek myth about Aphrodite's origins. In the story, preserved in Hesiod's Theogony 147-206, Kronos castrates Uranos, and the genitals are cast into the sea where the foam covers them. Out of this mess emerges Aphrodite, who is nurtured by the foam but is then washed ashore. Oleson thinks that Jude is familiar with this story and the waves are thus the opponents, who bring to shore the castrated genitals which, in turn, symbolise the adversaries' disgusting and licentious state (Oleson 1978-1979:496). In Greek mythology, it is true that the 'foam borne' Aphrodite was not only associated with love, but with murky dimensions, including associations with 'rape, adultery, incest and wantonness' (Charles 1993:163). Given the author's facility and knowledge of Greek, it would not be surprising if he was thinking of Aphrodite and her origins as he upheld his attacks on the false teachers here. As Charles observes, the imagery 'serves up a graphic picture of [the] opponents. They have a precedent - in Israel's past as well as that of the pagan Greeks' (1993:163).

In verses 14-15 Jude cites from the prophecy of 1 Enoch 1:9 and applies it to his opponents in verse 16 . The prophecy reiterates the emphasis upon the ungodliness of these people; to both their deeds and their words. The ungodly not only committed ungodly actions, they said harsh things against the Lord (v. 15). Verse 16 then brilliantly connects the prophecy to the opponents in the letter. These people are

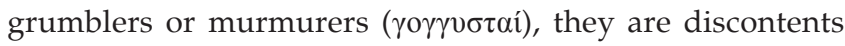

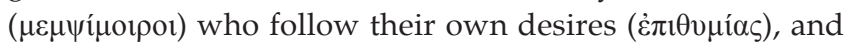

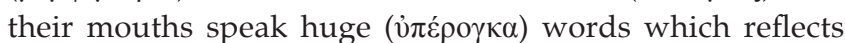
their arrogance and contempt for God and all authority. At the end of the verse, Jude states that these opponents are

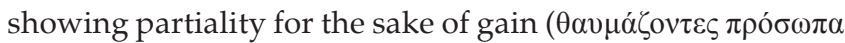

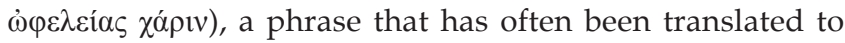
refer to flattery. The reference has something to do with displaying partiality in order to gain benefits, whether it means that the opponents show partiality to the rich, as in James $2: 1-9$, or perhaps they are simply currying favours from whomever they can receive them. Either way, it creates an image of a sycophant (Bauckham 1983:100). These are people who will say the right thing in order to further their own interests, not for the sake of anyone else. In addition, they lack discipline in their speech. They grumble and murmur, follow their own passions, and speak honeyed words if they see an advantage to doing so. Neyrey (1993) sums up this theme in Jude very well:
Inasmuch as Jude's rivals speak flattering words, contest traditional doctrine, and threaten the place of traditional authority roles, he perceives their lack of oral control as a direct threat to the wholeness and holiness of the social body as he knows it. (p. 79)

The false teachers' lack of 'mouth control' is perhaps not surprising, given their purported inability to reign themselves in in other areas of bodily restraint.

Jude's peroratio consists of verses 17-23. The author repeats the main proposition of his argument, which he does by claiming that the false teachers scoff at the predictions of the apostles, and instead, follow their own 'ungodly passions' (v. 18). Here we do not expect to see more specific charges but a reinforcement of the argument already made, and it is worth noticing that not only the ungodliness of the scoffers is mentioned, but the fact that they follow their own passions. Again, the author refers to the adversaries as yvхıкоi (v. 19), which recalls the characterisation of them as irrational animals who follow their own instincts. The author then appeals to the audience's emotions in verses 20-23, providing exhortation both for how to build up the community, and how to save those who may doubt or come close to being infected by the adversaries. Jude is graphic here; he states that his audience must hate even the garment that is soiled by the flesh of the opponents. Again, he is rendering it clear that these opponents are polluted. Even touching a piece of clothing that the scoffers have touched or worn would have a corrupting influence. Such an image underlines to what extent the author associates these enemies with 'fleshiness' and corruption. In contrast, the addressees are to remain 'without blemish' as Jude states in his doxology (vv. 24-25) and he closes on a positive note, with a reassuring stress on God's majesty and power (v. 25).

Unlike some Graeco-Roman writers who employ invective, Jude does not describe the physical appearance, gestures or tone of voice of his opponents. Nor does Jude try to make people laugh at his adversaries. He eschews any attempt to be amusing, unlike some of the Graeco-Roman satirists and poets of the era. However, this does not mean that the audience would not pick up on the insinuations he is making about the opponents. Jude is a serious letter, deeply concerned that his audience avoid these false teachers whose influence places the health and survival of the community in jeopardy. However, the repeated references to his opponents' lack of control, whether it is with regard to sexual behaviour, emphasised the most, their antics at the common meal, or their speech, are consistent with the major thematic emphases within Graeco-Rome invective that targets people as effeminates and violators of a natural order. Wherever Jude's audience was, the characterisation of these opponents would have strongly suggested that they were effeminate and as such, aberrant. As a Judean, entrenched in a rich set of literary traditions not shared by most Greek and Roman writers, Jude incorporates stories and prophecies familiar to him and connects them to the fate of his enemies. He thus assures his audience that these effeminate infiltrators have long been condemned, and that they will be sure to meet the awful fate of those who have engaged in such sinful and egregious behaviour in the past. 


\section{Conclusion}

In his commentary on Jude and 2 Peter, Neyrey (1993) has rightly indicated how the authors of these texts have represented their opponents in a deeply a dishonourable manner. Such a characterisation would be damning in a culture in which honour and shame were pivotal values that pertained to almost every dimension of life. These values were also gender based. There was no greater dishonour to the ancient Mediterranean male than to be associated with womanliness whether it had to do with one's physical features, dress, or actions. In specific, a lack of selfcontrol, whether it pertained to speech, sex, or desire for wealth, was a sure sign of effeminacy. In characterising his opponents as debauched and out of control, therefore, Jude has employed an effective rhetorical weapon as he seeks to neutralise a potential influence on his addressees. These aberrant infiltrators threaten to contaminate the community. By identifying them with some of the major features of an effeminate, and employing traditional texts and prophecies that assure their condemnation, Jude seeks to keep them at bay. Not surprisingly, later writers would find the letter of Jude to be a useful ally and tool as they battled opponents and other so-called 'heretics' in subsequent centuries. ${ }^{13}$

\section{Acknowledgements Competing interests}

The author declares that she has no financial or personal relationship(s) that may have inappropriately influenced her in writing this article.

\section{References}

Allen, J.S., 1998, 'A new possibility for the three clause format of Jude 22-23', New Testament Studies 44, 133-143. http://dx.doi.org/10.1017/S0028688500016404

Bauckham, R.J., 1983, Jude, 2 Peter, Word Books, Waco. (Word Biblical Commentary, 50).

Callan, T., 2009, 'Comparison of humans to animals in 2 Peter 2, 10b-22', Biblica 90, 101-113.

Charles, J.D., 1993, Literary strategy in the epistle of Jude, University of Scranton Press, Scranton.

Charles, J.D., 2008, 'Polemic and Persuasion: Typological and rhetorical perspectives on the Letter of Jude', in R.L. Webb \& P.H. Davids (eds.), Reading Jude with new eyes. Methodological reassessments of the letter of Jude, pp. 81-108, T \& T Clark, London. (Library of New Testament Studies, 383).

13.In the 16th century, for example, Ambrosius Catharinus writes a commentary on Jude that functions as a polemic against Protestant reformers. The reformers are identified with the opponents in Jude. See Preston (2002).
Corbeill, A., 1996, Controlling laughter. Political humor in the late Roman republic, Princeton University Press, Princeton.

Corbeill, A., 1997, 'Dining deviants in Roman political invective', in J.P. Hallett \& M.B. Skinner (eds.), Roman sexualities, pp. 99-128, Princeton University Press, Princeton.

Desjardins, M., 1987, 'The portrayal of the dissidents in 2 Peter and Jude: Does it tell us more about the "Godly" than the "Ungodly"?', Journal for the Study of the New Testament 30, 89-102.

Edwards, C., 1993, The politics of immorality in ancient Rome, Cambridge University Press, Cambridge.

Edwards, C., 1997, 'Unspeakable professions: Performance and prostitution in Ancient Rome', in J.P. Hallett \& M.B. Skinner (eds.), Roman sexualities, pp. 66-95, Princeton University Press, Princeton.

Gleason, M., 1990, 'The semiotics of gender: Physiognomy and self-fashioning in the second century', in D.M. Halperin, J.J. Winkler \& F.I. Zeitlin (eds.), The construction of erotic experience in the ancient Greek world, pp. 389-415, Princeton University Press, Princeton.

Joubert, S.J., 1995, 'Persuasion in the Letter of Jude', Journal for the Study of the New Testament 58, 75-87. http://dx.doi.org/10.1177/0142064X9501705805

Kamen, D., 2014, 'Kina[i]dos: A pun in Demosthenes' On the Crown?' Classical Quarterly 64, 405-408. http://dx.doi.org/10.1017/S0009838813000827

Kelly, J.N.D., 1969, A commentary on the epistles of Peter and of Jude, Adam and Charles Black, London. (Black's New Testament commentaries).

Mayor, J.B., 1907, The epistle of St. Jude and the epistle of St. Peter, Macmillan and Co., Ltd, London.

Moxnes, H., 1997, 'Conventional values in the Hellenistic World: Masculinity', in P. Bilde, T. Engberg-Pedersen, L. Hannestad \& J. Zahle (eds.), Conventional values of the Hellenistic Greeks, pp. 263-284, Aarhus University Press, Aarhus. (Studies in Hellenistic Civilization, 8)

Neyrey, J.H., 1993, 2nd Peter and Jude. A new translation and commentary, Doubleday, New York. (Anchor Bible 37C)

Oleson, J.P., 1978-1979, 'An Echo of Hesiod's Theogony vv. 190-192 in Jude 13', New Testament Studies 25, 492-503.

Pelikan, J. (ed.), 1963, Luther's works, vol. 35, Concordia, St Louis.

Preston, P., 2002, 'Ambrosius Catharinus' commentary on the general Epistle of St Jude', Reformation and Renaissance Review 4, 217-229. http://dx.doi. org $/ 10.1558 /$ rrr.v4i2.217

Richard, E.J., 2000, Reading 1 Peter, Jude, and 2 Peter, Smyth and Helwys, Macon. (Reading the New Testament Series).

Richlin, A., 1988, 'Systems of food imagery in Catullus', The Classical World 81, 355363. http://dx.doi.org/10.2307/4350229

Richlin, A., 1992, The garden of Priapus. Sexuality and aggression in Roman humor rev. edn., Oxford University Press, New York.

Rowston, D., 1975, 'The most neglected book in the New Testament', New Testament Studies 21, 554-563. http://dx.doi.org/10.1017/S0028688500010031

Upson-Saia, K., 2011, Early Christian dress: Gender, virtue and authority, Routledge, New York. (Routledge Studies in Ancient History, 3).

Walters, J., 1997, 'Invading the Roman Body: Manliness and impenetrability in Roman thought', in J.P. Hallett \& M.B. Skinner (eds.), Roman sexualities, pp. 29-43, Princeton University Press, Princeton.

Watson, D.F., 1988, Invention, arrangement, and style. Rhetorical criticism of Jude and 2nd Peter, Scholars Press, Atlanta. (Society of Biblical Literature Dissertation Series, 104).

Webb, R.L. \& Davids, P.H. (eds.), 2008, Reading Jude with new eyes: Methodological reassessments of the letter of Jude, T \& T Clark, London. (Library of New Testament Studies, 383).

Williams, C.A., 1999, Roman homosexuality: Ideologies of masculinity in classical antiquity, Oxford University Press, New York.

Wisse, F., 1972, 'The Epistle of Jude in the history of Heresiology', in M. Krause (ed.), Essays on the Nag Hammadi texts in honour of Alexander Böhlig, pp. 133-143, Brill, Leiden. (Nag Hammadi Studies, 3). 